\title{
Nitrogen Fertilization and Liming Improves Growth, Production, Gas Exchange and Post-Harvest Quality of Yellow Flower Jambu
}

\author{
Vivian Christine Nascimento Costa
}

Soil Science department, Institute of Agrarian Sciences, Federal Rural University of Amazon, CEP. 066.077-830. Belém, Pará, Brasil. E-mail: vivian.costa.1993@ gmail.com

\section{Mário Lopes da Silva Júnior}

Soil Science department, Institute of Agrarian Sciences, Federal Rural University of Amazon, CEP. 066.077-830. Belém, Pará, Brasil. E-mail: mario.silva_junior@yahoo.com.br

\section{Italo Marlone Gomes Sampaio}

Soil Science department, Institute of Agrarian Sciences, Federal Rural University of Amazon, CEP. 066.077-830. Belém, Pará, Brasil. E-mail: italofito@gmail.com

\section{Ricardo Falesi Palha de Moraes Bittencourt}

Soil Science department, Institute of Agrarian Sciences, Federal Rural University of Amazon, CEP. 066.077-830. Belém, Pará, Brasil. E-mail: ricardofalesibitten@ gmail.com

\section{Stefany Priscila Reis Figueiredo}

Soil Science department, Institute of Agrarian Sciences, Federal Rural University of Amazon, CEP. 066.077-830. Belém, Pará, Brasil. E-mail: stefanyyreis23@gmail.com

\section{Gabriel Anderson Martins dos Santos}

Soil Science department, Institute of Agrarian Sciences, Federal Rural University of Amazon, CEP. 066.077-830. Belém, Pará, Brasil. E-mail: gabrmartins20@gmail.com 
Soil Science department, Institute of Agrarian Sciences, Federal Rural University of Amazon, CEP. 066.077-830. Belém, Pará, Brasil. E-mail: leonelrodrigus@gmail.com

\author{
Eder Silva de Oliveira \\ Environmental and Sanitary Engineering department, State University of Pará, \\ CEP. 68740 - 000. Belém, Pará, Brasil. E-mail: ederso@uepa.br
}

Received: Mar. 19, 2020

doi:10.5296/jas.v8i3.16720
Accepted: May 27, 2020 Published: May 29, 2020

URL: https://doi.org/10.5296/jas.v8i3.16720

\begin{abstract}
Jambu is a vegetable, widely consumed in the Brazilian North Region, both in typical foods and medicinal herb. Despite its versatility, there are uncountable challenges in relation to its cultivation, especially with regard to the availability of information on nutritional management, such as the lack of data on the effect of liming associated with the supply of nitrogen $(\mathrm{N})$ on the production performance of the crop. Thus, the effect of nitrogen fertilization and liming on growth, production, physiological responses and post-harvest quality of the yellow-flowered variety jambu was evaluated. The experimental design was randomized in factorial blocks $(6 \times 2)$, with five repetitions. The treatments consisted in the combination of six doses of $\mathrm{N}\left(0 ; 60 ; 90 ; 120 ; 150\right.$ and $\left.180 \mathrm{~kg} \mathrm{ha}^{-1}\right)$ with and without liming application $(0$ and $70 \% \mathrm{~V})$. The variables of growth, production, gas exchange and post-harvest quality of jambu were evaluated. Standardly, there was interaction between $\mathrm{N}$-dose and liming factors for most of the analyzed variables, except for titratable acidity and total soluble solids and titratable acidity ratio. In general, the increasing of $\mathrm{N}$ doses combined with liming positively affected growth, production, physiological responses and post-harvest quality, and it was observed that in the $170 \mathrm{~kg} \mathrm{ha}^{-1}$ dose of $\mathrm{N}$ higher response was obtained in the biomass accumulation of the aerial part and in the $180 \mathrm{~kg} \mathrm{ha}^{-1}$ dose of $\mathrm{N}$ maximum production of inflorescences. Therefore, the use of correctives associated with nitrogen fertilization is recommended to obtain more significant production and quality of jambu.
\end{abstract}

Keywords: Acmella oleracea, biomass, soil correction

\title{
1. Introduction
}

"Jambu" (Acmella oleracea (L.) R.K. Jansen) is a vegetable, widely consumed in the North region, being used in typical foods and for medicinal purposes. It has a peculiar taste, and the leaves, stems and inflorescences produce a sensation of tingling and numbness of the mouth mucous membranes, due to the presence of the spilanthol substance (Borges et al., 2014). This vegetable has become very promising in the Brazilian markets due to its importance in gastronomy and international industries because of the relative increase of patents for new 
spilanthropic products. (Borges et al., 2014; Gusmão; Gusmão, 2013).

However, despite the great applicability of jambu in industry and gastronomy, some challenges are still faced in relation to its cultivation, especially in regard to the availability of information on nutrient supply, as well as soil correction practices, where it is noted that studies relating the practice of liming with increased efficiency of fertilization and jambu performance do not exist (Sampaio et al., 2018). According to Menezes Júnior et al. (2012), the agronomic performance of a species is generally related to its adaptation to the place of cultivation and to the management practices adopted in its production, such as fertilization and liming.

In this sense, the use of liming as a practice for soil acidity correction has been widely explored, due to the positive responses both in improving soil attributes (Rodrighero et al., 2015), as well as in the efficiency of fertilizer use (Raij, 2011). Among the main benefits of liming, it is worth mentioning the elevation of $\mathrm{pH}$, increase in calcium and magnesium contents, neutralization of toxic aluminium $\left(\mathrm{Al}^{+3}\right)$ from the soil, and greater absorption of nitrogen $(\mathrm{N})$, phosphorus $(\mathrm{P})$ and potassium $\left(\mathrm{K}^{+}\right)$(Cardoso et al., 2014; Victoria et al., 2019).

Among the essential elements of plants, $\mathrm{N}$ is the nutrient that most contributes to the physiological metabolism of plants and is directly related to the formation of proteins and pigments such as chlorophyll (Taiz et al., 2017). In general, both the yield and quality of leafy vegetables depend on an adequate supply of nitrogen (Filgueira, 2013).

Therefore, it is important to know the limiting factors and nutritional requirements of the jambu culture, in order to obtain information for fertilization and liming programs due to the lack of research on this subject. Thus, the objective of the work was to evaluate the effect of nitrogen fertilization and liming on growth, production, gas exchange and post-harvest quality of yellow flower variety of jambu.

\section{Materials and Methods}

The experiment was conducted under greenhouse conditions, at the Agrarian Sciences Institute of Federal Rural University of the Amazon - UFRA, the experiment took place from January to March 2019. The geographical coordinates are $48^{\circ} 26^{\prime} 14^{\prime \prime} \mathrm{W}$ and $1^{\circ} 27^{\prime} 22^{\prime \prime} \mathrm{S}$, with $6.37 \mathrm{~m}$ of altitude. The climate classification is Af according to Köppen and Geiger, the average temperature is $26.8{ }^{\circ} \mathrm{C}$ and the average annual rainfall is $2.537 \mathrm{~mm}$ (Alvares et al., 2013).

The soil from the experimental area was collected at a depth of 0-0.2 $\mathrm{m}$ and classified as Dystrophic Yellow Oxisol, sandy texture (Embrapa, 2013). The chemical and granulometric analyses of the soil were obtained from composite sample (Table 1) according to Embrapa (2013) methodology. 
Table 1. Chemical and granulometric attributes of Yellow Latosol, layer 0-0.2 m, before the limestone incubation

\begin{tabular}{|c|c|c|c|c|c|c|c|c|}
\hline \multicolumn{2}{|c|}{$\mathrm{pH}$} & $\mathrm{P}$ & $\mathrm{K}^{+}$ & $\mathrm{Ca}^{+2}$ & $\mathrm{Mg}^{+2}$ & $\mathrm{Al}^{+3}$ & $(\mathrm{H}+\mathrm{Al})$ & SB \\
\hline $\mathrm{H}_{2} \mathrm{O}$ & $\mathrm{KCl}$ & \multicolumn{2}{|c|}{$\mathrm{mg} \mathrm{dm}^{-3}$} & ------. & ------. & $-\mathrm{cmol}_{\mathrm{c}}$ & -3 ------- & ----- \\
\hline 5.0 & 3.8 & 18.0 & 39.0 & 2.5 & 0.4 & 1.5 & 6.1 & 3.0 \\
\hline $\mathrm{T}$ & $\mathrm{T}$ & V & M & Corg. & M.O & Sand & Silt & Clay \\
\hline \multicolumn{2}{|c|}{$\mathrm{cmol}_{\mathrm{c}} \mathrm{dm}^{-3}$} & \multicolumn{2}{|c|}{$\%$} & & ------- & $g^{-1}---$ & & ---- \\
\hline 4.5 & 9.1 & 32.9 & 33.3 & 18.7 & 32.2 & 855.5 & 76.8 & 67.7 \\
\hline
\end{tabular}

\subsection{Experimental Design and Treatments}

The experimental design was randomized blocks in factorial arrangement (6 x 2), with five repetitions. The treatments consisted in the combination of control (no supply of $\mathrm{N}$ ) and five doses of $\mathrm{N}\left(60 ; 90 ; 120 ; 150\right.$ and $\left.180 \mathrm{~kg} \mathrm{ha}^{-1}\right)$ with and without liming application ( 0 and $70 \% \mathrm{~V})$, using two yellow-flowered jambu plants per five-liter pot.

\subsection{Seedling and Soil Preparation}

The liming doses were calculated in accordance with the base saturation criterion stipulated for $5 \mathrm{mg} \mathrm{dm}^{-3}$ of soil according to the methodology of (Cravo et al., 2007). The liming was done 35 days before the transplant, using dolomitic limestone $\left(\mathrm{CaCO}_{3} . \mathrm{MgCO}_{3}\right)$ with Relative power of total neutralization (PRNT) equal to $91 \%$, containing $32 \% \mathrm{CaO}$ and $15 \% \mathrm{MgO}$.

The determined amount of limestone was incorporated to the soil in plastic bags with a capacity of 10 liters, in which it was homogenized at weekly intervals. For the incorporation of limestone, the bags were moistened up to approximately $80 \%$ of the field capacity (Brazil,1992) For humidity control, the bags were weighed daily in a scale with a capacity of $15 \mathrm{~kg}$ and an accuracy of $0.1 \mathrm{~g}(0.001 \%)$ and remoistened when necessary with distilled water. Soil chemical analysis was performed after liming was incubated (Table 2).

Table 2. Chemical attributes of Yellow Latosol, layer 0-0.2 m, after incubation of limestone

\begin{tabular}{|c|c|c|c|c|c|c|c|c|c|c|c|c|}
\hline \multicolumn{2}{|c|}{$\mathrm{pH}$} & $\mathrm{P}$ & $\mathrm{K}$ & $\mathrm{Ca}$ & $\mathrm{Mg}$ & $\mathrm{Al}$ & $(\mathrm{H}+\mathrm{Al})$ & SB & $\mathrm{t}$ & $\mathrm{T}$ & $\mathrm{V}$ & $\mathrm{m}$ \\
\hline $\mathrm{H}_{2} \mathrm{O}$ & $\mathrm{KCl}$ & \multicolumn{2}{|c|}{$\mathrm{mg} \mathrm{dm}{ }^{3}$} & \multicolumn{7}{|c|}{ 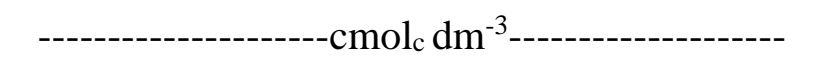 } & \multicolumn{2}{|c|}{$\%$} \\
\hline 5.5 & 5.2 & 44.0 & 78.0 & 3.1 & 1.9 & 0.2 & 2.9 & 5.9 & 5.4 & 8.1 & 64.3 & 3.7 \\
\hline
\end{tabular}

Source: Laboratory of Soil Analysis - UFRA, 2019. 
The jambu yellow flower genotype was obtained from the active germplasm bank in the horticultural sector linked to the Institute of Agrarian Sciences (ICA) from UFRA. Whose coordinates are $01^{\circ} 27^{\prime} 19^{\prime \prime} \mathrm{S}$ and $48^{\circ} 26^{\prime} 20^{\prime \prime} \mathrm{O}$. The jambu was sown in trays of polystyrene expanded to 128 cells, using the sieved humus as substrate. 10 seeds per cell were sown in order to guarantee two seedlings per cell at the time of transplant. The tray containing the seedlings was been placed on a nursery bench receiving nutrient solution of Hoagland and Arnon (1950) at half ionic strength. The seedlings were transplanted 20 days after sowing.

\subsection{Fertilization}

The application of $\mathrm{N}$ for each treatment was plotted three times, being $20 \%$ in the planting fertilization and $80 \%$ in the coverage. The cover fertilization occurred at fifteen-day intervals. A nutritional solution of urea $\left(\mathrm{CH}_{4} \mathrm{~N}_{2} \mathrm{O}\right)$ to one molar was used to supply the $\mathrm{N}$. The supply of the other macro and micronutrients followed the recommendations of Cravo et al. (2007).

\subsection{Irrigation}

The irrigation management was performed by the daily weighing method of the pot set $(\mathrm{V})+$ wet soil $(\mathrm{W})+$ plant $(\mathrm{P})$, the irrigations were effective when the set weight was less than $80 \%$ of field capacity. The missing volume was completed with distilled water. To correct the weight of the pots due to the increase in fresh matter, the average weight of two plants taken from each treatment at 25, 35 and 45 days after transplanting the seedlings was added to the weight of each pot according to Pereira et al. (2003). Two pots per treatment were considered for weight measurement.

\subsection{Parameters Growth and Production}

Harvesting was performed 55 days after sowing, when the following variables were analyzed:

2.5.1 Total leaf area $\left(\mathrm{AL} ; \mathrm{cm}^{2}\right.$ plant $\left.^{-1}\right)$ : It was determined with the use of a leaf area integrator (LI-COR, LI 3000);

2.5.2 Length of the aerial part (LAP; $\mathrm{cm}$ ): it was determined with the aid of a metric ruler, measuring if the plant from the stem base to its apex;

2.5.3 Number of inflorescences (NI; unit per plant ${ }^{-1}$ ): it was obtained by counting the inflorescences of each experimental unit.

2.5.4 Fresh mass of the aerial part (FMA; g plant ${ }^{-1}$ ) and fresh mass of inflorescence (FMI; $g$ plant $^{-1}$ ); was determined by weighing biomass part of the plants in precision scale with four decimal places;

2.5.5 Dry mass of the aerial part (DMA; g plant ${ }^{-1}$ ) and dry mass inflorescence (DMI; $g$ plant $\left.^{-1}\right)$; were determined by the weight of the biomass part that was dried in a forced air oven at $65{ }^{\circ} \mathrm{C}$ until reaching constant mass.

\subsection{Physiological Parameters}

One day before the harvest, an analysis of gas exchange in the plants were performed. The evaluations were carried out in the morning, between 9:00 and 11:00 AM. The liquid 
photosynthesis rate $\left(A, \mu\right.$ mol $\left.\mathrm{CO}_{2} \mathrm{~m}^{-2} \mathrm{~s}^{-1}\right)$, stomatic conductance $\left(g s, \mu \mathrm{mol} \mathrm{H}_{2} \mathrm{O} \mathrm{m}^{-2} \mathrm{~s}^{-1}\right)$, internal $\mathrm{CO}_{2}$ concentration $\left(C i, \mu \mathrm{mol}\right.$ mol-1) transpiration $\left(E, \mu \mathrm{mol} \mathrm{m} \mathrm{m}^{-2} \mathrm{~s}^{-1}\right)$, carboxylation efficiency $\left(E i C, \mu \mathrm{mol} \mathrm{m} \mathrm{m}^{2} \mathrm{~s}^{-1}\right.$ ) were evaluated, obtained by the ratio between $A$ and $C i$, instantaneous water use efficiency (WUE, mmol $\mathrm{CO}_{2} \mathrm{~mol}^{-1} \mathrm{H}_{2} \mathrm{O}$ ), obtained by the ratio between $A$ and $E$ and intrinsic water use efficiency (WiUE, mmol $\mathrm{CO}_{2} \mathrm{~mol}^{-1} \mathrm{H}_{2} \mathrm{O}$ ), obtained by the ratio between $A$ and $g s$. The photosynthesis, internal $\mathrm{CO}_{2}$ concentration, conductance and transpiration were obtained through a portable infrared gas analyzer (IRGA, model LI 6400XT, LICOR® brand).

\subsection{Post Harvest Parameters}

2.7.1 Titratable acidity (TA): determined in $1 \mathrm{~g}$ of macerated leaf, transferred to a $125 \mathrm{ml}$ Erlenmeyer flask and filled to $50 \mathrm{ml}$ with distilled water. The phenolphthalein indicator at $1 \%$ was used and titration with $0.1 \mathrm{~N} \mathrm{NaOH}$ solution was performed. The results were expressed as (\%) of oxalic acid. (Adolfo Lutz Institute, 2008);

2.7.2 Hydrogen ionic potential $(\mathrm{pH})$ : the $\mathrm{pH}$ was determined from $1 \mathrm{~g}$ of macerated and diluted leaf ( $1 \mathrm{~g}$ of leaf / $30 \mathrm{ml}$ of distilled water) using a digital potentiometer with glass membrane (Adolfo Lutz Institute, 2008);

2.7.3 Soluble solids (SS): determined by digital refractometer with automatic temperature correction, from the maceration in mortar of $1.0 \mathrm{~g}$ of leaf with $1.0 \mathrm{~mL}$ of distilled water, homogenized, filtered and the results were expressed in percentage (\%) (Adolfo Lutz Institute, 2008);

2.7.4 Ratio TSS / TA: determined by the quotient between soluble solids and titratable acidity.

\subsection{Data Analysis}

The data were submitted to normality analysis by the Shapiro-Wilk test. The analysis of variance by the $\mathrm{F}$ test $(\mathrm{p}<0.05)$ was applied to prove the standard distribution of results and, when significant, the regression study was performed. For data analysis we used the statistical program Sisvar version 5.6 (Ferreira, 2011)

\section{Results and Discussion}

\subsection{Growth}

The values of LAP, AL and NI were influenced by both $\mathrm{N}$ and limestone doses with significant interaction $(\mathrm{p}<0.05)$ between both factors (Figure 1). 

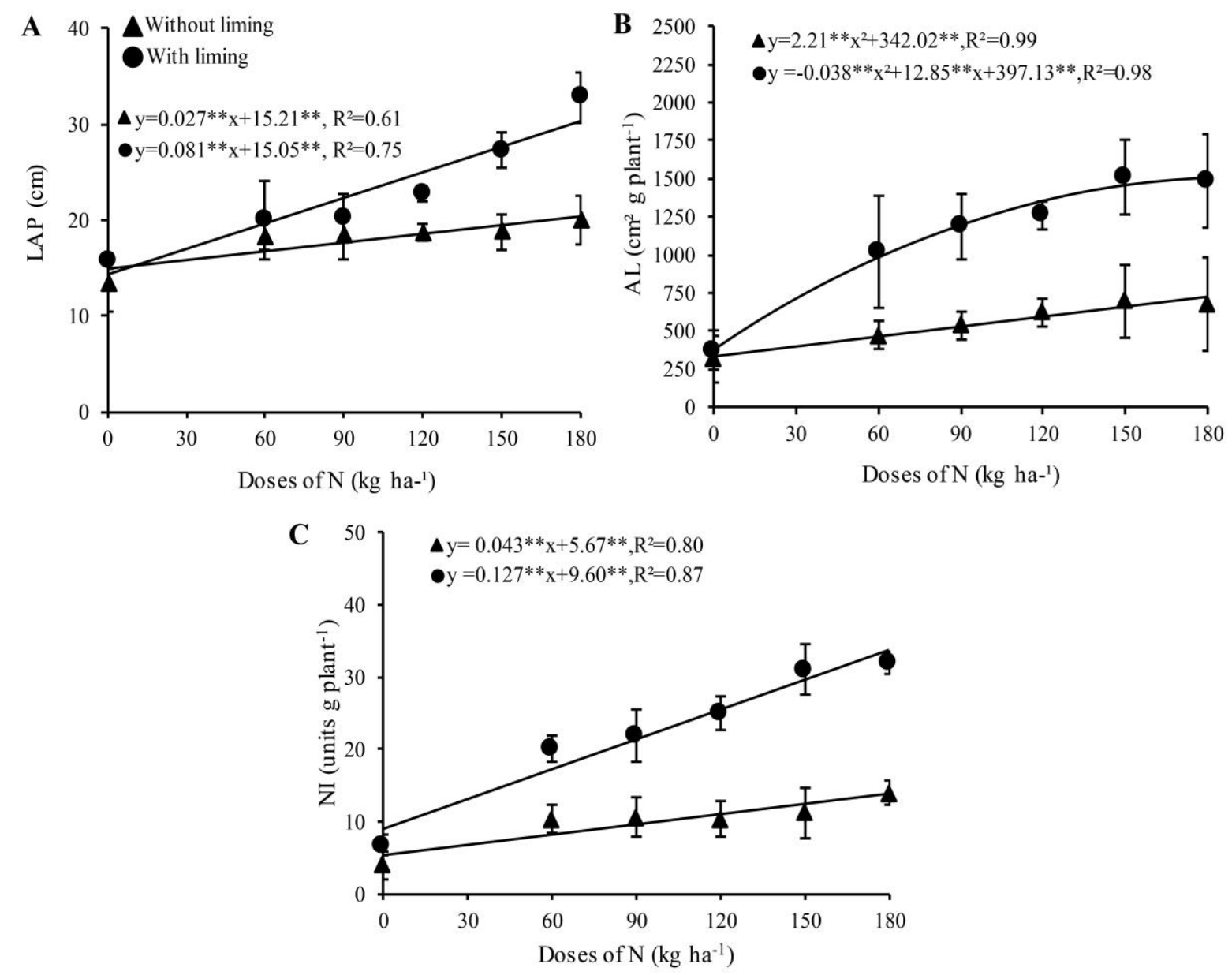

Figure 1. Length of the aerial part -LAP (A), leaf area- AL(B) and number of inflorescencesNI (C) as a function of nitrogen doses and liming application ( $\boldsymbol{\Delta}$ without liming and $\bullet$ with liming) on the yellow flower jambu variety. The vertical lines are standard deviation.** $\mathrm{e}^{*}$ -

Significant at 1 and 5\% for the "t- student" test

The $\mathrm{N}$ doses promoted a significant effect of the LAP of the jambu, independent of the limestone dose, with the increasing linear model being the one that best adjusted to the data. Thus, as the $\mathrm{N}$ dose increased, there was an increase in the aerial part of the plants with the maximum value reached of $32.8 \mathrm{~cm}$ in the dose of $180 \mathrm{~kg}$ of $\mathrm{N} \mathrm{ha}^{-1}$ associated with the application of limestone, which represented an increase of approximately $64 \%$ for the same dose without the presence of limestone (Figure 1A).

The $\mathrm{N}$ is an element that influences the processes involved in the growth and development of plants, as it is closely related to photosynthesis, respiration, ionic absorption, as well as cellular multiplication. In addition, it is a constituent of molecules such as chlorophyll, proteins, RNA and DNA (Taiz et al., 2017). In this sense, it can be noted that the greater availability of $\mathrm{N}$ had a positive effect on the growth of the aerial part of the jambu, as observed in other studies with the species (Borges et al., 2014; Souto et al., 2018; Aviz et al., 2020). 
Aviz et al. (2020) evaluating the effect of irrigation slides and $\mathrm{N}$ doses on growth and jambu production, found that increased $\mathrm{N}$ application to the soil promoted plant growth. Uniformly, Borges et al. (2014) and Souto et al. (2018) studying nitrogen fertilizer sources in jambu varieties obtained positive responses at plant height with mean values of 37.36 and $35.42 \mathrm{~cm}$, respectively. Gusmão \& Gusmão (2013) cited that jambu plants can reach 20 to $40 \mathrm{~cm}$ in height depending on the cultivation system, management and soil and climate conditions.

It was equally detected that the application of lime associated with nitrogen fertilization obtained the maximum value of LAP from the plants, which can be explained by the increase in the levels of some essential nutrients in the soil solution (Table 2) promoted by liming, such as $\mathrm{Ca}$ and $\mathrm{Mg}$, since these elements act in processes of protein synthesis, carbohydrates and growth regulation (Atkinson, 2014; Engels, 2012). In addition, there was a decrease in the concentration of $\mathrm{Al}$ by approximately $87 \%$ (Table 2), and the value of $1.5 \mathrm{cmol}_{\mathrm{c}} \mathrm{dm}^{-3}$ obtained before liming was classified as toxic (Cravo et al., 2007). Al in concentrations considered toxic promotes reductions in the growth of the aerial part of plants due mainly to its effects on root shortening and thickening, thus promoting reductions in water and nutrient absorption (Fontes, 2016). This may explain the lower growth of plants that did not receive limestone (Figure 1A).

For AL, the dose of $\mathrm{N}$ in the soil increased significantly, observing the formation of distinct models with and without application of limestone. With soil correction the effect of $\mathrm{N}$ availability in the soil was adjusted to a quadratic function with maximum estimated response of $1.483 .8 \mathrm{~cm}^{2}$ at a dose of $169.11 \mathrm{~kg} \mathrm{ha}^{-1}$ of $\mathrm{N}$ (Figure 1B). When comparing the highest response of the estimated dose of plants developed in the environment with correction of the best performance achieved without correction, which was represented by an increasing linear function, it is verified that the application of limestone increased approximately $120 \%$ to AL.

The increase in AL with the increased availability of $\mathrm{N}$ may be related to the structural function performed by $\mathrm{N}$, such as in the formation of proteins and amino acids, being it primordial for the formation of compounds essential to the metabolism of the plant and processes such as photosynthesis (Taiz et al., 2017). According to Cardoso and Hiraki, (2001) the adequate supply of $\mathrm{N}$ allows the expansion of the photosynthetic area, which can promote growth and productive potential of vegetables.

Peçanha et al. (2019) evaluating the nutritional dynamics of jambu inducing symptoms of deficiency of macronutrients and boron in nutrient solution, observed significant reduction in leaf area only for treatment under omission of $\mathrm{N}$, which demonstrates the importance of this nutrient in expanding leaf area in the species.

In addition, it is also highlighted that the increased response of $\mathrm{N}$ with the application of limestone may be related to the higher availability of $\mathrm{Ca}$ and $\mathrm{Mg}$, which obtained their elevated levels in 24 and $375 \%$, respectively, if compared to the soil that did not receive limestone. This fact may have contributed to the increase of the foliar area of plants submitted to liming. According to Liang et al. (2018) these elements have structural importance in the plant, acting in the expansion and cell division. Standardly, $\mathrm{Ca}$ is essential to maintain the structural and functional integrity of membranes and cell wall. The most 
important function of $\mathrm{Mg}$ is to be a key element in the biosynthesis of chlorophyll, a molecule of vital importance in the photosynthesis process (Malavolta, 2006).

The NI as a function of $\mathrm{N}$ and limestone doses were adjusted to linear functions, observing a higher response (32 plant $^{-1}$ inflorescences) obtained in the $180 \mathrm{~kg} \mathrm{ha}^{-1}$ dose of $\mathrm{N}$ associated with the application of limestone, which represents an increase of $129 \%$ if compared to the same dose of $\mathrm{N}$ without application of limestone (Figure 1C).

The increase in the number of inflorescences due to the increased application of $\mathrm{N}$ in the soil is possibly related to the increase in nutritional demand due to the phenological stage of the plant, especially regarding the reproductive phase, as also observed in vegetables such as lettuce (Martins et al., 2009).

Rodrigues et al. (2014) demonstrated the importance of $\mathrm{N}$ for the reproductive phase of jambu, because as $\mathrm{N}$ doses in the soil increased, there was a linear increase in the number of inflorescences per plant. On the other hand, Peçanha et al. (2019) evaluating the performance of jambu in nutritional sufficiency and omission of nutrients, observed that plants deficient in $\mathrm{N}$ obtained the lowest production of inflorescences, as well as delayed the reproductive phase compared to other nutrients, a result that reinforces the importance of $\mathrm{N}$ in the reproductive performance of jambu.

Moreover, not only the $\mathrm{N}$, but the nutrients $\mathrm{Ca}$ and $\mathrm{Mg}$ contained in the limestone are fundamental for the emission of floral chapters in the jambu, as observed by Peçanha et al. (2019), where they observed that the omission of $\mathrm{Ca}$ and $\mathrm{Mg}$ in Acmella oleracea, reduced by $27 \%$ the number of floral chapters if compared with adequately nourished plants, thus demonstrating the importance of $\mathrm{N}, \mathrm{Ca}$ and $\mathrm{Mg}$ in the maintenance of the reproductive capacity of the species.

Thus, it can be perceived that the growth variables of jambu are responsive to the increased availability of $\mathrm{N}$ and the application of limestone in the soil, due to the linear responses obtained, indicating that the plant can still express greater responses in higher concentrations of nutrients in the soil, especially $\mathrm{N}$ due to its importance in improving the growth, production and quality of jambu, as already demonstrated in other studies (Borges et al., 2014; Rodrigues et al., 2014; Aviz et al., 2020; Sampaio et al., 2020).

\subsection{Production}

The productive characteristics were influenced by both $\mathrm{N}$ and limestone doses, with significant interaction $(\mathrm{p}<0.05)$ between both factors (Figure 2$)$. 

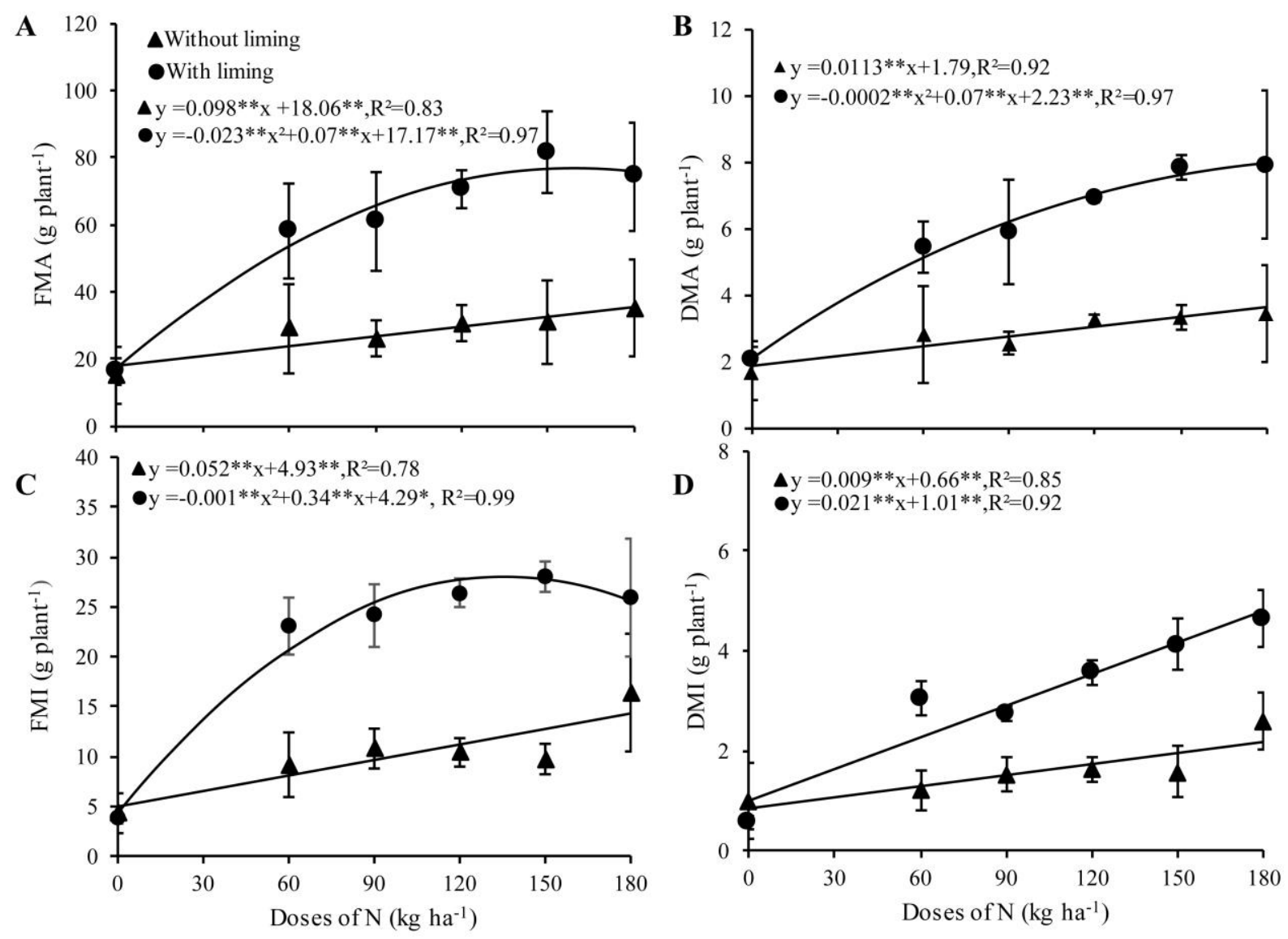

Figure 2. Fresh mass of the aerial part - FMA (A), dry mass of the aerial part - DMA (B), fresh mass of Inflorescence- FMI (C) and dry mass inflorescence- FMI (D) as a function of nitrogen doses and liming application ( $\boldsymbol{\Delta}$ - without liming; $\bullet$ - with liming) on the yellow flower jambu variety. The vertical lines are standard deviation. ${ }^{*}$ and $*$ - Significant at 1 and $5 \%$ for the "t- student" test

Regarding FMA and DMA, soils that received lime application as a function of $\mathrm{N}$ doses adjusted to the quadratic model, where maximum estimated yields (76.98 and $7.79 \mathrm{~g} \mathrm{plant}^{-1}$ ) were found in doses of 160 and $171 \mathrm{~kg}$ of $\mathrm{N} \mathrm{ha}^{-1}$, respectively. In contrast, soils that did not receive correction had linear increase. Thus, liming provided an increase of $111 \%$ for FMA and $130 \%$ for DMA in relation to the maximum value reached with $\mathrm{N}$ doses without application of lime, which indicates that application of lime increases the efficiency of $\mathrm{N}$ use in biomass production by the jambu plant (Figure 2A and 2B).

Similar to the results, Mantovani et al. (2005) observed quadratic adjustment for productivity by cultivating different lettuce cultivars as a function of the increase in the $\mathrm{N}$ dose, i.e., they observed a reduction in the biomass of the aerial part of the plants from the $176 \mathrm{~kg} \mathrm{ha}^{-1}$ dose of N. For jambu, in general, little work is observed regarding the effect of nitrogen fertilization on the productive performance of the crop (Borges et al., 2013; Aviz et al., 2020; Sampaio et al., 2020). Thus, Borges et al. (2013) evaluating the effect of nitrogen fertilization on jambu with curral dung and urea, observed that the increase in the dose of these fertilizers 
in the soil promoted accumulation of fresh and dry mass from the aerial part, highlighting fertilization with urea that obtained better performance.

In contrast to the results obtained for the growth variables (Figure 1), it can be observed that the FMA and DMA variables, from a certain concentration of $\mathrm{N}$ associated with liming, were reduced. It is likely that this reduction is related to the increase of nutrients in the soil as $\mathrm{N}$, $\mathrm{Ca}$ and $\mathrm{Mg}$. According to Marschner (2012) the excess of an element or nutrients in the soil causes a change in the mineral composition of plants due to ionic interactions that can lead to a nutritional disorder either by deficiency of an element or by toxicity. In addition, changes in the mineral composition of plants can promote changes in physiological processes fundamental to plant growth and development, such as photosynthesis (Taiz et al., 2017).

For the FMI, different regression models were developed. Application of limestone associated with $\mathrm{N}$-doses was adjusted to a quadratic function with estimated maximum production of $27.92 \mathrm{~g}$ plant $^{-1}$ at dose $139 \mathrm{~kg} \mathrm{ha}^{-1}$. On the other hand, $\mathrm{N}$ doses without lime application were explained by an increasing linear function. That is, the maximum dose of $\mathrm{N}$ $\left(180 \mathrm{~kg} \mathrm{ha}^{-1}\right)$ tested promoted the maximum production of FMI (16.33 $\left.\mathrm{g} \mathrm{plant}^{-1}\right)$, however with a difference of less than $71 \%$ in relation to the best response observed with limestone application (Figure 2C).

In relation to DMI, it was observed that, independent of the application of limestone, the $\mathrm{N}$ doses promoted an increase, which was explained by linear functions. The maximum production obtained when lime was applied with a dose of $180 \mathrm{~kg} \mathrm{ha}^{-1}$ of $\mathrm{N}$ was $4.65 \mathrm{~g} \mathrm{plant}^{-1}$, this indicates an increase of $79 \%$ in comparison to the same dose without addition of lime (Figure 2D).

The results obtained corroborate those reported by Rodrigues et al. (2014), where for MFI and MSI, there was formation of positive linear models as a function of the $\mathrm{N}$ doses applied in a soil cultivation system. Other studies show the beneficial effect of $\mathrm{N}$ fertilization on the production of melancholy fruits (Barros et al., 2012), paprika (Santos et al., 2020) and Chamomile (Roza et al., 2016).

Phenological stages directly influence the nutritional demand of plants, with flowering and fruiting being the periods of higher nutrient demand, since inflorescences and fruits represent draining organs with high demand for photo assimilates to reach maturity (Marschner, 2012; Taiz et al., 2017), a behavior that may explain the increase in fresh and dry mass production of jambu inflorescence with increased availability of $\mathrm{N}, \mathrm{Ca}$ and $\mathrm{Mg}$ in the soil, resulting from nitrogen fertilization and liming. Reinforcing this result, Peçanha et al. (2019) observed that $\mathrm{N}$ is the most accumulated nutrient in the inflorescences of jambu plants. According to the authors, this may be related to the high mobility of $\mathrm{N}$ in the plant phloem, facilitating its transport to the drainage organs, as is the case of inflorescences, thus highlighting its contribution to the production of the same.

The increase of biomass in the aerial part is desired by jambu culture because both leaves, stem and inflorescences, are commercialized in Brazil (Sampaio et al., 2018). Thus, soil management from the use of correctives together with nitrogen fertilization prove to be 
indispensable for the production performance of jambu.

\subsection{Post-Harvest Quality}

There was significant interaction $(\mathrm{p}<0.05)$ between the $\mathrm{N}$ dose factors and limestone for $\mathrm{pH}$ only. The post-harvest characteristics TA and TSS/TA were influenced by N doses (Figure 3). For TSS there was no significant effect of the factors tested or in isolation.
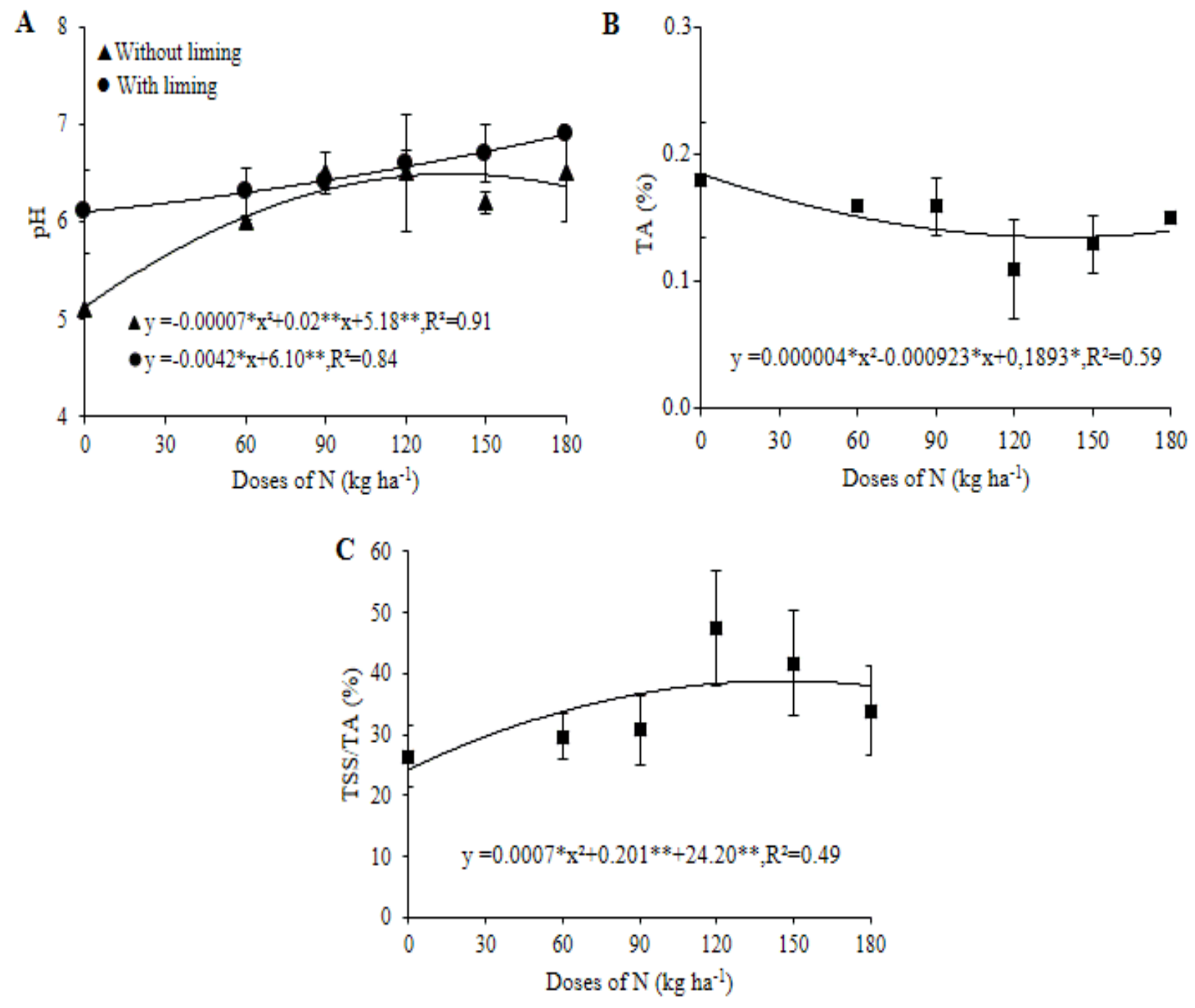

Figure 3. Hydrogen ionic potential- pH (A), Titratable acidity- TA (B) and Ratio TSS / TA (C) as a function of nitrogen doses and liming application ( $\boldsymbol{\Delta}$ - without liming; $\bullet$ - with liming) on the yellow flower jambu variety. The vertical lines are standard deviation. $* *$ and $*_{-}$

\section{Significant at 1 and 5\% for the "t- student" test}

Regarding the $\mathrm{pH}$, it can be observed that the levels of $\mathrm{N}$ with application of lime, followed increasing linear behavior, reaching a maximum value of 6.9. However, for the doses of $\mathrm{N}$ without liming, a quadratic regression model with a higher $\mathrm{pH}$ value (6.6) obtained in the dose of $136 \mathrm{~kg} \mathrm{ha}^{-1}$ of $\mathrm{N}$ is observed (Figure 3A). Kano et. al (2010), in a study of cauliflower quality as a function of $\mathrm{N}$ doses, observed an increase in the $\mathrm{pH}$ value as a function of increased $\mathrm{N}$ availability in the soil. 


\section{Macrothink}

The TA adjusted to the quadratic model according to the $\mathrm{N}$ doses (Figure 3B), where it was verified that the increase of the $\mathrm{N}$ supply provided reduction of the acidity until the dose of $115 \mathrm{~kg} \mathrm{ha}^{-1}$ of $\mathrm{N}$, that from this dose there was increase. Thus, the decrease in oxalic acid promoted by the increased availability of $\mathrm{N}$ is a desirable characteristic for the post-harvest quality of jambu, since the reduction in the concentration of organic acids makes the plants more palatable (Chitarra \& Chitarra, 2005).

As for TSS/TA, there was quadratic adjustment with maximum estimated response of $38.8 \%$ at $145 \mathrm{~kg} \mathrm{ha}^{-1}$ of $\mathrm{N}$ (Figure $3 \mathrm{C}$ ). In another analysis, without comparing the maximum estimated response with the result of the lower dose $\left(25 \mathrm{~kg} \mathrm{ha}^{-1}\right.$ of $\left.\mathrm{N}\right)$, there was an increase of approximately $47 \%$ in this proportion, which indicates a greater predominance of sugars over acids in the leaves, hence, making the leaves more palatable (Lemos Neto et al., 2018).

For jambu, the increase in the TSS/TA ratio is an interesting response to the post-harvest quality of the crop, since it indicates a higher proportion of sugars in detriment of acids, giving a better taste (Chitarra \& Chitarra, 2005). According to Filgueira (2013), N at adequate soil levels governs the productivity and quality of leafy vegetables.

\subsection{Gas Exchanges}

There was a significant interaction $(\mathrm{p}<0.05)$ between $\mathrm{N}$ and liming doses for the analyzed gas exchange variables, with the exception of water use efficiency (WUE) which was uninfluenced by the interaction of factors or by them in isolation (Figure 4). 


\section{Macrothink}
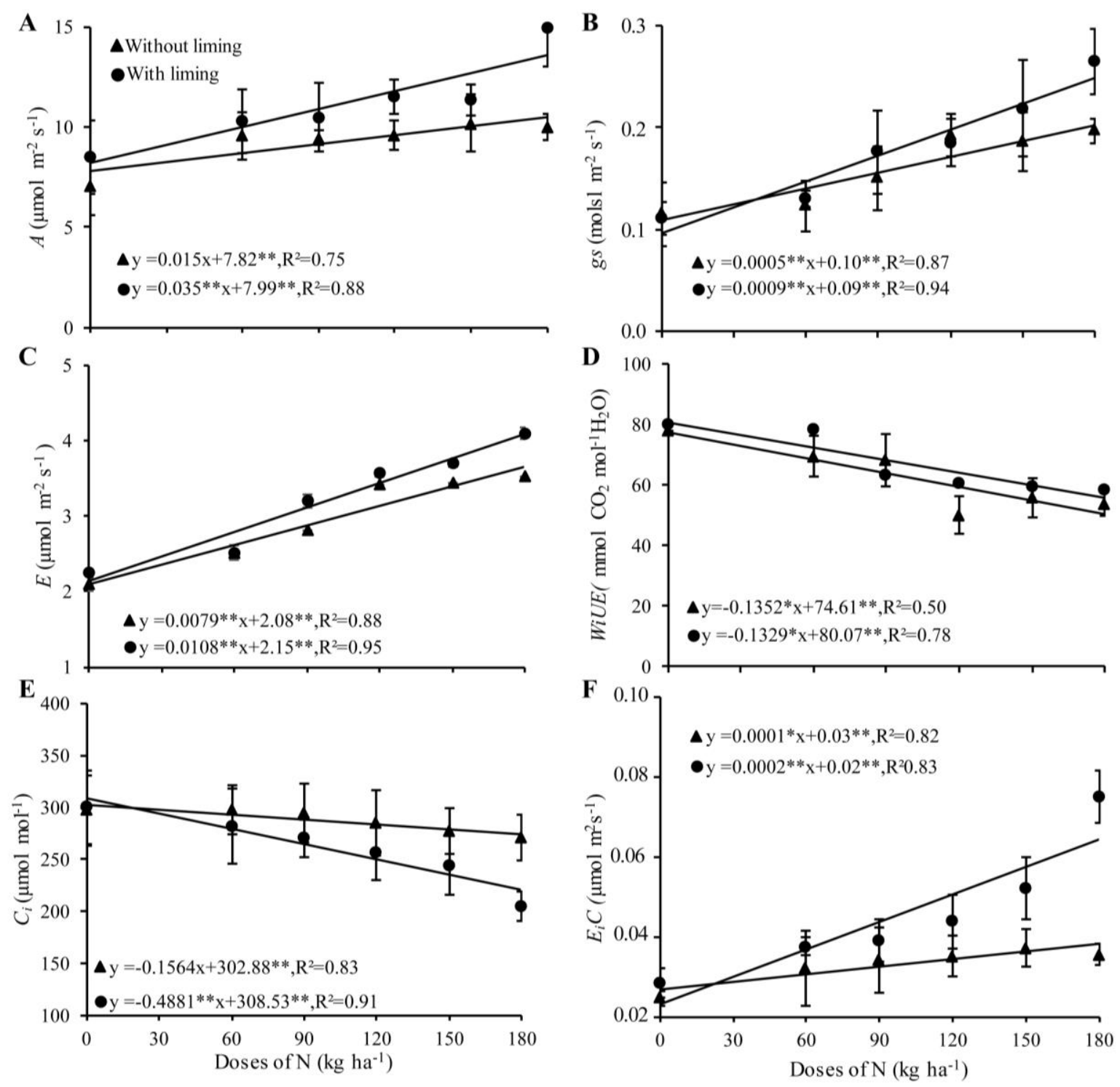

Figure 4. Liquid photosynthesis rate - $A(\mathrm{~A})$, stomatic conductance - $g s(\mathrm{~B})$, transpiration - $E$

(C), intrinsic water use efficiency - WiUE (D), internal $\mathrm{CO}_{2}$ concentration - $\mathrm{Ci}(\mathrm{E})$ and carboxylation efficiency - EiC (D) as a function of nitrogen doses and liming application ( $\mathbf{A}$ without liming; • - with liming) on the yellow flower jambu variety. The vertical lines are standard deviation. $* *$ and $*$ - Significant at 1 and $5 \%$ for the "t- student" test

$A$ (Figure 4A) and $g s$ (Figure 4B) grew linearly as a function of the increase of $\mathrm{N}$ supply in the soil, independent of the lime dose. Therefore, it is highlighted that the $180 \mathrm{~kg} \mathrm{ha}^{-1}$ dose of $\mathrm{N}$ associated with lime application promoted a $50 \%$ increase in the photosynthetic rate and $34 \%$ in the stomach opening in relation to the same dose without lime addition.

As for $E$, as it raised the levels of $\mathrm{N}$ applied in the soil, independent of the limestone dose, there was a proportional increase in perspiration rates, which was adjusted to an increasing linear function. Thus, it was verified that the dose of $180 \mathrm{~kg} \mathrm{ha}^{-1}$ of $\mathrm{N}$ combined with limestone promoted higher $\mathrm{E}\left(4.09 \mu \mathrm{mol} \mathrm{m} \mathrm{m}^{-2}\right)$ if compared to the same dose without 
application of limestone, representing an increase of $17 \%$ in the transpiration rate (Figure 4C).

The increase in photosynthesis response, transpiration and stomatic conductance as $\mathrm{N}$ doses were increased associated with soil correction - which promoted an increase in $\mathrm{Ca}$ and $\mathrm{Mg}$ levels and a significant reduction in $\mathrm{Al}$ in the soil (Table 2), may explain the increase in plant growth, production and quality. To such a degree, the supply of these nutrients stimulated a greater opening of the stomach pore, which allowed the entry of $\mathrm{CO}_{2}$, and an increase in the rate of transpiration of the plants that may have benefited an increase in the rate of absorption of nutrients by the plants that, consequently, promoted the highest photosynthetic rates observed (Figure 4A).

Both $\mathrm{N}$ and $\mathrm{Mg}$ are part of the chlorophyll molecule, acting in protein synthesis and $\mathrm{CO}_{2}$ fixation (Akram et al., 2011; Chen et al., 2018). Ca plays an active role in stoma closure, because it acts as a secondary messenger in stoma regulation, in addition, it has influence on the formation of the leaf area, the vital organ in photosynthetic activity (Marschner, 2012). On the other hand, the insufficient supply of these elements can promote nutritional disorders in the plant, culminating in changes in the photosynthetic chain of transport of electrons and/or the enzymatic system of fixation of $\mathrm{CO}_{2}$, thus occurring negative effects on the photosynthetic rate, which compromised the growth and development of the plant (Taiz et al., 2017).

The WiUE decreased linearly with the elevation of the $\mathrm{N}$ supply in the soil, independent of the limestone dose. The higher $\mathrm{N}$ dose $\left(180 \mathrm{~kg} \mathrm{ha}^{-1}\right)$ decreased the WiUE approximately 30\% in relation to the control treatment $\left(90 \mathrm{~kg} \mathrm{ha}^{-1}\right.$ of $\left.\mathrm{N}\right)$ for both corrected and non-corrected soils.

The decrease of the WiUE can be justified by the linear growth of $g s$ and $E$ promoted by the increased availability of $\mathrm{N}$. Under adequate hydric conditions, as occurred in this test, there will be greater stomatic opening, consequently, greater loss of water by transpiration, however, with increased photosynthesis products which promote gains in growth and accumulation of biomass (Taiz et al., 2017).

As for $\mathrm{Ci}$, a decreasing linear model was observed, independent of the presence and absence of liming, therefore, as the level of $\mathrm{N}$ in the soil increased, there was an equal reduction in the internal concentration of $\mathrm{CO}_{2}$, with the most substantial reductions obtained in the $180 \mathrm{~kg}$ $\mathrm{ha}^{-1}$ dose of $\mathrm{N}$ (Figure 4E).

The reduction of $\mathrm{Ci}$ observed in this study with the increase of $\mathrm{N}$ supply is justified due to the incorporation of $\mathrm{CO}_{2}$ in carbon structures (Rocha et.al, 2019), being this fact proven due to the increasing linear increase of the instantaneous carboxylation efficiency (Figure 4F) that obtained maximum value in soils with liming and in the highest $\mathrm{N}$ dose. These results reinforce, as observed for the other analyzed variables, that $\mathrm{N}$ positively influences the physiological responses and that these are optimized by soil correction. 


\section{Conclusion}

The growth and production variables of jambu are increased with the elevation of the nitrogen level in the soil, achieving better responses at levels between 170 and $180 \mathrm{~kg} \mathrm{ha}^{-1}$ of $\mathrm{N}$.

The quality parameters $\mathrm{pH}, \mathrm{TA}$ and TSS/TA are positively influenced by nitrogen fertilization.

Nitrogen fertilization promotes increased photosynthesis, stomatic conductance, transpiration and carboxylation efficiency in jambu plants.

Liming increases nitrogen fertilization responses in all variables analyzed, except for AT and TSS/TA.

\section{Acknowledgment}

To CNPq for granting the scholarship to the first author. The Amazon Foundation for the Support of Studies and Research (Fapespa) for granting an academic doctorate, ICAAF No. 009/2017, to the trird author.

\section{References}

Adolfo Lutz Institute. (2008). $1^{\mathrm{a}}$ Edição Digital. Physical-Chemical Methods for Food Analysis. p.1020.

Alvares, C. A., Stape, J. L., Sentelhas, P. C., De Moraes Gonçalves, J. L., \& Sparovek, G. (2013). Köppen's climate classification map for Brazil. Meteorologische Zeitschrift, 22(6), 711-728. https://doi.org/10.1127/0941-2948/2013/0507

Akram, M., Ashraf, M. Y., Jamil, M., Iqbal, R. M., Nafees, M., \& Khan, M. A. (2011). Nitrogen application improves gas exchange characteristics and chlorophyll fluorescence in maize hybrids under salinity conditions. Russian Journal of Plant Physiology, 58(3), 394-401. https://doi.org/10.1134/S1021443711030022

Atkinson, C. J. (2014). Is xylem sap calcium responsible for reducing stomatal conductance after soil liming? Plant and Soil, 382(1-2), 349-356. https://doi.org/101007/11104-014-2180-z

Aviz, W. L. C., de Lima, J. A., da Silva, A. L. P., Gomes, R. F., Souza, R. O. R. de M., Santos, H. C. A., \& de Oliveira, P. D. (2019). Productivity of jambu (Acmella oleracea) using different soil water tensions and nitrogen rates under greenhouse condition. Australian Journal of Crop Science, 13(3), 360-366. https://doi.org/10.21475/ajcs.19.13.03.p1178

Barros, Márcio M., Araújo, Wellington F., Neves, Leandro T. B. C., Campos, André J. de, \& Tosin, Jéssica M. (2012). Produção e qualidade da melancia submetida a adubação nitrogenada. Revista Brasileira de Engenharia Agrícola e Ambiental,16(10), 1078-1084. https://doi.org/10.1590/S1415-43662012001000007

Borges, L.S., Guerrero, A.C., Goto, R., \& Lima, G. P. P. (2014). Morpho-physiological indices and productivity of jambu cultivars influenced by organic and mineral fertilization. 
Bioscience Journal, 30(6), 1768-1778.

Borges, L. S., Guerrero, A. C., Goto, R., \& Lima, G. P. P. (2013). Productivity and accumulation of nutrients in plants of jambu, under mineral and organic fertilization. Semina: Ciências Agrárias, 83-94. https://doi.org/10.5433/1679-0359.2013v34n1p83

Brasil. (1992). Ministério da Agricultura e Reforma Agrária. Secretaria Nacional de Defesa Agropecuária. Departamento Nacional de Produção Vegetal. Coordenação de Laboratório Vegetal. Rules for Seed Analysis. Brasília, DF, 1992. 365p.

Cardoso, A. I. I., \& Hiraki, H. (2001). Evaluation of doses and times of application of calcium nitrate on radish culture. Horticultura Brasileira, 19(3), 328-331. https://doi.org/10.1590/S0102-05362001000300007

Cardoso, A. A. de S., Santos, J. Z. L., Tucci, C. A. F., \& Barbosa, T. M. B. (2014). Accumulation of nutrients and growth of pepper as a function of doses of limestone. Revista Agro@Mbiente On-Line, 8(2), 165. https://doi.org/10.18227/1982-8470ragro.v8i2.1881

Chen, Z. C., Peng, W. T., Li, J., \& Liao, H. (2018). Functional dissection and transport mechanism of magnesium in plants. Seminars in Cell and Developmental Biology, 74, 142-152. https://doi.org/10.1016/j.semcdb.2017.08.005

Chitarra, M. I. F., \& Chitarra, A. B. (2005). Post-harvest of fruits and vegetables: physiology and handling. Lavras: UFLA. 785p.

Cravo, M. da S., Viégas, I. de J. M., \& Brasil, E. C. (2007). Fertilization and liming recommendations for the state of Pará. Belém-PA: Embrapa Amazônia Oriental, 262p.

EMBRAPA (Empresa Brasileira de Pesquisa Agropecuária). (2013). Centro Nacional de Pesquisa de Solos. Manual of soil analysis methods. 3 ed. Rio de Janeiro.

Engels, C., Kirkby, E., \& White, P. (2012). Mineral Nutrition, Yield and Source-Sink Relations. In: Marschner, P., Ed., Marschner's Mineral Nutrition of Higher Plants, 3rd edition, Elsevier, Berlin, 101. http://dx.doi.org/10.1016/B978-0-12-384905-2.00005-4

Ferreira, D. F. (2011). Sisvar: a computer statistical analysis system. Ciência e Agrotecnologia, 35(6), 1039-1042. https://doi.org/10.1590/S1413-70542011000600001

Filgueira, F. A. R. (2013). New olericulture manual: modern agro-technology in vegetable production and marketing. 3. ed. rev. e ampl. Viçosa: UFV, 2013421 p.

Fontes, P. C. R. (2016). Nutrição Mineral de Plantas: anamnese e diagnóstico. Viçosa, Editora UFV. $315 \mathrm{p}$

Gusmão, M. T. A., \& Gusmão, S. A. L. (Eds.). (2013). Amazonian Jambu: Acmella oleracea, (L.) RK Jansen: general characteristics, convencional, organic and hydroponic cultivation. 135p. UFRA, Universidade Federal Rural da Amazônia.

Hoagland, D. R., \& Arnon, D. I. (1950). The water-culture method for growing plants without soil. Circular. California agricultural experiment station, 347 (2nd edit). 
Pereira, O. C. N., Bertonha, A., Freitas, P. S. L., Gonçalves, A. C. A., Rezende, R., \& Silva, F. F. da. (2003). Lettuce production as a function of water and nitrogen. Acta Scientiarum. Agronomy, 25(2), 381-386. https://doi.org/10.4025/actasciagron.v25i2.1987

Lemos Neto, H. D. S., Guimarães, M. D. A., Mesquita, R. O., Gomes Sampaio, I. M., Hendges, A. R. A. de A., \& De Oliveira, A. B. (2018). Silicon Potential as Attenuator of Salinity Effects on Growth and Post-harvest Quality of Lettuce. Journal of Agricultural Science, 10(7), 455. https://doi.org/10.5539/jas.v10n7p455

Liang, C., \& Zhang, B. (2018). Effect of exogenous calcium on growth, nutrients uptake and plasma membrane $\mathrm{H}^{+}$-ATPase and $\mathrm{Ca}^{2+-}$ ATPase activities in soybean (Glycine max) seedlings under simulated acid rain stress. Ecotoxicology and Environmental Safety, 165(September), 261-269. https://doi.org/10.1016/j.ecoenv.2018.09.019

Mantovani, J. R., Ferreira, M. E., \& Cruz, M. C. P. da. (2005). Produção de alface e acúmulo de nitrato em função da adubação nitrogenada. Horticultura Brasileira, 23(3), 758-762. https://doi.org/10.1590/s0102-05362005000300014

Martins, C. M.; Medeiros, J. F.; Lopes, W. A. R.; Braga, D. F.; Amorim, L. B. (2009). Curve of absorption of nutrients in hydroponic lettuce. Revista Caatinga, 22(4), 123-128.

Malavolta, E. (2006) Manual de nutrição mineral de plantas, São Paulo, Agronômica Ceres. $638 \mathrm{p}$.

Marschner, P. (Ed.) (2012). Marschner's mineral nutrition of higher plants. 672 p. Academic press._https://doi.org/10.1016/C2009-0-63043-9

Menezes Júnior, Francisco Olmar G de, \& Vieira Neto, João. (2012). Onion production according to plant density. Horticultura Brasileira, 30(4), 733-739. https://doi.org/10.1590/S0102-05362012000400028

Peçanha Alves, D., Mendonça Freitas, M. S., Evangelista Vieira, M., Capato Lima, T., \& de Souza Gonçalves, Y. (2019). Characterization of deficiency symptoms and mineral nutrient content in Acmella oleracea cultivated under macronutrient and boron omissions. Journal of Plant Nutrition, 42(8), 879-890. https://doi.org/10.1080/01904167.2019.1584216

Raij, B. V. (2011). Soil fertility and nutrient management. Piracicaba: IPNI.

Rocha, M. E. L., Coutinho, P. W. R., Abade, M. T. R., Inagaki, A. M., Cadorin, D. A., \& Hoepers, L. M. L. (2019). Morphophysiology of cabbage plants under liquid humus concentrations. Revista de Ciências Agroveterinárias, 18(4), 438-443. https://doi.org/10.5965/223811711842019438

Rodrigues, D. S., Camargo, M. S., Nomura, E. S., Garcia, V. A., Correa, J. N., \& Vidal, T. C.M. (2014). Influence of the fertilization with nitrogen and phosphorus in the production of jambu (Acmella oleracea (L) R.K. Jansen). Revista Brasileira de Plantas Medicinais, 71-76. https://doi.org/10.1590/S1516-05722014000100010 
Rodrighero, Maik Barbosa, Barth, Gabriel, \& Caires, Eduardo Fávero. (2015). Surface application of limestone with different magnesium contents and granulometries in a no-tillage system. Revista Brasileira de Ciência do Solo, 39(6), 1723-1736. https://doi.org/10.1590/01000683rbcs20150036

Roza, L. A., Pauletti,;, Deschamps, V. 1,; Santos, C. ${ }^{2}$;, \& A L ${ }^{1}$. (2016). Adubação nitrogenada no rendimento da camomila [Chamomilla recutita (L.) Rauschert]. Rev. Bras. Pl. Med, 773-778. https://doi.org/10.1590/1983-084X/0027

Sampaio, I. M. G. O., Guimarães, M. A., Neto, H. S. L., Maia, C. L., Viana, C. S., \& Gusmão, S. A. L. (2018). Can the use of grouped seedlings and higher planting density increase jambu productivity? Revista de Ciências Agrárias, 61, 1-8. https://doi.org/10.22491/rca.2018.2906

Sampaio, I. M. G., Silva Júnior, M. L. da, Chagas, E. D. S., Bittencourt, R. F. P. de M., Costa, V. C. N., Souza, D. L. de, ... Texeira, B. J. B. (2020). Evaluation of the Non-destructive Method Efficiency of Estimating Nitrogen Content in Jambu Plants Grown in Hydroponic System. Journal of Agricultural Studies, 8(2), 466. https://doi.org/10.5296/jas.v8i2.16380

Santos, H. C. A., Lima, Junior, J. A. D., Silva, A. L. P. D., Castro, G. L. S. D., \& Gomes, R. F. (2020). Yield of Fertigated Bell Pepper Under Different Soil Water Tensions and Nitrogen Fertilization1. Revista Caatinga,33(1), 172-183. Epub March 23, 2020. https://doi.org/10.1590/1983-21252020v33n119rc

Souto, G. C., Grangeiro, L. C., de Gusmão, S. A. L., de Sousa, V. de F. L., Cavalcante, A. E. C., $\&$ de França, F. D. (2018). Agronomic performance of jambu (Acmella oleracea) using organic fertilization. Australian Journal of Crop Science, 12(1), 151-156. https://doi.org/10.21475/ajcs.18.12.01.pne819

Taiz, L., Zeiger, E., Moller, I. M., \& Murphy, A. (2017). Plant physiology and development. Porto alegre: Artmed.

Victoria, O., Ping, A., Yang, S., \& Eneji, E. (2019). Liming and Nitrogen Effects on Maize Yield and Nitrogen Use Efficiency. Communications in Soil Science and Plant Analysis, 50(16), 2041-2055. https://doi.org/10.1080/00103624.2019.1648663

\section{Copyright Disclaimer}

Copyright for this article is retained by the author(s), with first publication rights granted to the journal.

This is an open-access article distributed under the terms and conditions of the Creative Commons Attribution license (http://creativecommons.org/licenses/by/4.0/). 